\title{
EFFECT OF MATERIAL AND FERMENTATION TIME ON QUALITY AND DIGESTIBILITY OF COMPLETE FEED, AVERAGE DAILY GAIN OF BLIGON GOAT AND FARMER'S INCOME
}

\author{
B. Suwignyo, L.L. Munawaroh and I .G S. Budisatria \\ Faculty of Animal Science, Gadjah Mada University, \\ Jl. Fauna No. 3, Bulaksumur, Yogyakarta 55281 - Indonesia \\ Corresponding E-mail: bsuwignyo@ugm.ac.id
}

Received January 13, 2015; Accepted February 24, 2015

\begin{abstract}
ABSTRAK
Penelitian ini bertujuan untuk mengetahui pengaruh bahan dan lama fermentasi terhadap kualitas dan kecernaan complete feed, pertambahan bobot badan harian (PBBH) kambing Bligon jantan dan pendapatan peternak. Penelitian selama 12 minggu di kandang kelompok tani Purwomanunggal, Panggang, Gunung Kidul. Pakan komplit tersusun atas berbagai bahan pakan lokal untuk 15 ekor kambing Bligon jantan umur delapan bulan dengan bobot awal 12 sampai $15 \mathrm{~kg}$. Ternak terbagi dalam tiga kelompok yaitu $\left(\mathrm{R}_{0}\right)$ perlakuan kontrol, $\left(\mathrm{R}_{1}\right)$ diberi pakan complete feed yang difermentasi satu minggu, dan $\left(\mathrm{R}_{2}\right)$ diberi pakan complete feed yang difermentasi dua minggu. Data dianalisis dengan sidik ragam berdasarkan rancangan acak lengkap pola searah dan dilanjutkan dengan uji Duncan's multiple range test. Hasil menunjukkan bahwa complete feed yang difermentasi dua minggu cenderung mempunyai warna yang lebih tua dan bau yang lebih menyengat dibandingkan dengan complete feed yang difermentasi satu minggu. Kedua ransum mempunyai tekstur lunak dan tidak berjamur dengan kisaran $\mathrm{pH}$ 4,5 sampai 5,0. Perlakuan berpengaruh nyata terhadap konsumsi total digestible nutrient (TDN). Perlakuan pakan tidak berpengaruh nyata terhadap kecernaan acid detergent fiber (ADF) dan neutral detergent fiber (NDF), PBBH dan pendapatan peternak.
\end{abstract}

Kata kunci: fermentasi, complete feed, bahan lokal, Bligon, pendapatan

\begin{abstract}
The objectives of this research were to determine efect of material and fermentation time on quality and digestibility of fermented complete feed, average daily gain (ADG) of Bligon goats and farmer's income. The research was conducted during twelve weeks in the housing of goat farmers at Purwomanunggal farmers' group, Panggang, Gunung Kidul district. Fifteen Bligon male goats, 8 months of age and 12 to $15 \mathrm{~kg}$ of body weight, were randomly divided into three treatments, each groups consisted of five goats. The treatments were: control feed $\left(\mathrm{R}_{0}\right)$, one week fermented complete feed $\left(\mathrm{R}_{1}\right)$, and two weeks fermented complete feed $\left(\mathrm{R}_{2}\right)$. Data were analyzed with ANOVA based on one way completely randomized design and continued with Duncan's multiple range tests for significant differences. Result showed that complete feed fermented for two weeks had darker color and stronger odors compared with one week fermentation. Both fermented complete feed (one and two weeks) had soft textures, no fungi with $\mathrm{pH}$ ranged from 4.5 to 5.0. Total digestible nutrient (TDN) intake was significantly affected by the treatment. The treatment had no significant effect on acid detergent fiber (ADF) and neutral detergent fiber(NDF) digestibility, average daily gain, and farmer's income.

Keywords: fermentation, complete feed, local resources, Bligon, income
\end{abstract}




\section{INTRODUCTION}

Bligon is Indonesian local goat which has specification in terms of reproduction, produces kid throughout the year, well adapted in bad condition (season and feed), and high prolific. Goat performance is influenced by several factors, such as genetic and environment. Environmental factors are factors that exist around animal such as feed, disease, management, climate and others (Haryanto et al., 1997).

Utilization of local resources is one of a strategy to improve efficiency of goat production. The several of feedstuff are not only offering high flexibility for farmers, but also offer the complexity to the nutritionists to use it efficiently. In terms of quantity, fiber feed (high in lignocellulose content) is the highest availability surround. But, there are some constraints in the utilization of crop residues among others 1) low palatability, 2) low nutritional value, 3) relatively difficult handling (drying, milling, transport and storage), 4) seasonal availability, and 5) the potential use for other purposes.

One method that can be done to overcome the problems of feeding in Gunung Kidul, especially in the dry season is doing fermentation to the feedstuff to become complete feed. Improving the quality of feed through fermentation technology can reduce levels of fiber and increase the protein content. Fermentation changes the chemical structure of the substrate of complex compounds into simpler compounds, and eliminate anti-nutrient substances while improving the quality of the substrate.

Local material that can be used in making complete feed such as gliricidia leaves, corn straw, corn husks, banana stem, teak leaf, cassava, rice bran, and pollard. Complete feed is a feed that contains sufficient nutrients for livestock in certain physiological level. Complete feed is given as the only feed that is able to meet the basic needs of life and production without any additional substance other than water (Hartadi et al., 2005). Offering complete feed to animal can optimize consumption of feed without selection. Producing complete feed can be done with feed ingredients either concentrates or fibrous feed mixed in the form of feed. Produce complete feed which made from agricultural waste is one of the alternative solutions to the problems of continuity of supply of feed for ruminants (Purbowati et al., 2008). The objectives of this research were to determine the effect of material and fermentation time on the quality and digestibility of fermented complete feed, average daily gain (ADG) Bligon goats and farmer's income.

\section{MATERIALS AND METHODS}

\section{Materials}

Fifteen (15) male Bligon goats were used in this research, with body weight ranged from 12 to $15 \mathrm{~kg}$ and average of age was eight months. Goats were divided into three treatments and grouped according to body weight at each group consist of five goats, with five replications. Each group was given a different feed treatment. In the first group $\left(\mathrm{R}_{0}\right)$ goats were fed control diet, the second group $\left(R_{1}\right)$ goats were fed complete feed (one week fermentation), and the third group $\left(\mathrm{R}_{2}\right)$ goats were fed complete feed consisted of corn straw, corn husk, gliricidia, pollard, cassava, banana trees, rice bran, molasses, and Biofit ${ }^{\circledR}$ as inoculum. Control treatments consisted of gliricidia leaves and feed commonly used by breeders. Nutrient content of diet is presented in Table 1.

\section{Fermented Complete Feed}

Feed ingredients was collected, weighed, sun dried then milled using a hammer mill with the largest size of $0.5 \mathrm{~cm}$. Collected and milled feed ingredients were mixed, then added Biofit ${ }^{\circledR}$ that has been diluted with water, mixed until homogeneous. The complete feed consisted of corn straw $32 \%$, corn husk $5 \%$, gliricidia $30 \%$, teak leaf $6 \%$, cassava $6 \%$, rice bran $3 \%$, banana stover $12 \%$, molases $1 \%$, Biofit ${ }^{\circledR} 10 \mathrm{cc}$, water 1.5 liter, mineral $0.2 \mathrm{~g}$. Mixed diet (complete feed) were placed into airtight container for one and two weeks for fermentation processes, prior to be fed for goats. Feed samples from each treatment were analyzed for dry matter and organic matter content.

\section{Statistical analysis}

The parameters measured in this research were feed quality, average daily gain $(\mathrm{kg})$ and farmer's income. Data were analyzed with one way ANOVA using computer software Statistical Product and Service Solutions (SPSS) series 17 based on completely randomized design.

\section{RESULTS AND DISCUSSION}

\section{Quality of Fermented Complete Feed}

Qualityof fermented complete feed in this research was observed on the physical 
Table 1. Feed Ingredients and Nutrient Content of Diets

\begin{tabular}{lccc}
\hline \multicolumn{1}{c}{ Feed Ingredients (\%) } & $\mathrm{R}_{0}$ & $\mathrm{R}_{1}$ & $\mathrm{R}_{2}$ \\
\hline Gliricidia leaves & 75 & 20 & 20 \\
Corn straw & - & 20 & 20 \\
Corn husk & - & 3 & 3 \\
Cassava & - & 6 & 6 \\
Teak Leaves & 15 & 3 & 3 \\
Banana stem & - & 12 & 12 \\
Pollard & 6 & 6 & 6 \\
Rice bran & 3 & 3 & 3 \\
Mineral & 1 & 0.29 & 0.29 \\
Molasses & - & 1.20 & 1.20 \\
Biofit ${ }^{-}$ & - & 0.01 & 0.01 \\
Water & - & 25.50 & 25.50 \\
Total & 100 & 100 & 100 \\
Nutrients content of rations & & & \\
Crude protein (\%) & 16.08 & 11.00 & 11.57 \\
Crude fiber (\%) & 18.82 & 9.65 & 8.11 \\
Ether extract (\%) & 2.76 & 1.01 & 0.65 \\
Ash (\%) & 9.22 & 3.35 & 2.82 \\
\hline
\end{tabular}

characteristics (color, smell, texture and presence or absence of fungi), the chemical quality nutrient composition and the degree of acidity $(\mathrm{pH})$.

\section{Physical Characteristics}

Physical characteristics of fermented complete feed are presented in Table 2. All treatments of complete feed, either one or two week fermentation showed a distinctive odor of lactic acid fermentation. Lendrawati et al. (2008) stated that good silage will have smells like fermented milk because it contains lactic acid, not pungent odor. Fermented complete feed with two weeks fermentation have a more pungent odor due to longer time duration for fermentation. However, both fermented complete feed have a soft textures and not moldy.

McDonald (1981) stated that anaerobic fermentation will cause the feed is not brown or black, sour smell, not moldy, like the original texture and $\mathrm{pH}$ of 4.2 or less. According to Wallace and Chesson (1995), the change of color in anaerobic fermentation process can be caused by Maillard or browning reaction as a result of excessive heat production and increased acidity as a result of the dominance of lactic acid bacteria as long as fermentation process.

\section{Chemical Characteristics \\ PH Value}

The results showed that the $\mathrm{pH}$ value of the fermented complete feed either one or two weeks fermentation ranged from 4.5 to 5 . This result indicated that there was anaerobic fermentation activity. Lactic acid bacteria broke carbohydrates into lactic acid so that the $\mathrm{pH}$ of complete feed down to more acidic. Lendrawati et al. (2008) stated that $\mathrm{pH}$ value of less than 4 showed that fermented quality was good. The $\mathrm{pH}$ value of fermented complete feed was still the optimum $\mathrm{pH}$ for the activity of lactic acid bacteria. Djaafar et al. (1996) stated that the degree of acidity $(\mathrm{pH})$ which is optimum for the activity of lactic acid bacteria ranged from three to seven. Kamalidin et al. (2012) stated that the $\mathrm{pH}$ value of fermented complete feed with four days fermentation ranged 
from 3.90 to 4.45 .

The decrease of $\mathrm{pH}$ value during fermentation process was due to the soluble carbohydrate in complete feed that was available in sufficient quantities, so that it supports the activity of lactic acid bacteria to produce organic acids that was useful to lower the $\mathrm{pH}$ in the fermentor. Aside of soluble carbohydrates, protein content of complete feed was also low (11-12\%) so that the opportunity of Clostridium bacteria to dominate also become lower. To produce a good quality of fermented complete, the protein content of $10 \%$ is required (McDonald, 1981; Nusi et al., 2011). If feed ingredient contained high protein, decreasing of $\mathrm{pH}$ value during fementation processes can be inhibited. While Crowder and Cheeda (1982) stated that chemical composition of feed ingredient is affected by genotip (varietas), sampling method, and sample process.

\section{Nutrient Composition of Rations}

Nutrient composition of fermented complete feed is presented in Table 3. Based on Table 3, the chemical composition of the ration between $R_{1}$ and $\mathrm{R}_{2}$ was almost the same. The chemical composition of fermented complete feed with one and two week fermentation was not significantly different. The rations was formulated based on $12 \%$ isoprotein of body weight resulted $70.92 \%$ of TDN in $\mathrm{R}_{0}, 83.67 \%$ in $\mathrm{R}_{1}$, and $83.90 \%$ in $\mathrm{R}_{2}$. Value of TDN in the $\mathrm{R}_{0}$ was an accumulation of TDN from forage and concentrates.

The chemical composition of nutrients (DM, $\mathrm{OM}, \mathrm{CP}, \mathrm{CF}, \mathrm{EE}$ ) and TDN changed. The value of $\mathrm{CP}$ and $\mathrm{CF}$ decreased after fermentation process. According to Pujaningsih (2005), fermentation can reduce levels of fiber, transformed chemical structure of the substrate from complex compounds into simpler compounds, and eliminate anti nutrient substances. Reducing fiber and anti nutrient considered as improving the quality of the substrate. CF decreased at approximately $9.17 \%$ and it was lower than research by Sutarjo et al. (2011) about $12 \%$ but higher than Kamalidin et al. (2012) of approximately $4.31 \%$. Decreasing of $\mathrm{CF}$ value

Table 2. Physical Characteristics of Fermented Complete Feed, One Week $\left(R_{1}\right)$ and Two Weeks Fermentation $\left(\mathrm{R}_{2}\right)$

\begin{tabular}{lll}
\hline Variables & \multicolumn{1}{c}{$\mathrm{R}_{1}$} & \multicolumn{1}{c}{$\mathrm{R}_{2}$} \\
\hline Color & pale brownish yellow & Brownish yellow \\
Odor & Such as typical of lactic acid fermentation & $\begin{array}{l}\text { More sharp odor, such as typical of lactic } \\
\text { acid fermentation }\end{array}$ \\
Texture & Soft & Soft \\
Fungi & None & None \\
pH & 4.5 to 5.0 & 4.5 to 5.0 \\
\hline
\end{tabular}

Table 3. Chemical Composition of the Diets

\begin{tabular}{lrrr}
\hline \multicolumn{1}{c}{ Nutrients Content (\%) } & \multicolumn{1}{c}{$\mathrm{R}_{0}$} & \multicolumn{1}{c}{$\mathrm{R}_{1}$} & \multicolumn{1}{c}{$\mathrm{R}_{2}$} \\
\hline Dry matter (DM) & 91.42 & 92.82 & 93.37 \\
Ash & 9.22 & 3.35 & 2.82 \\
Crude protein (CP) & 16.08 & 11.00 & 11.57 \\
Crude fiber (CF) & 18.82 & 9.65 & 8,11 \\
Ether extract (EE) & 2.76 & 1.01 & 0.65 \\
Total Digestible Nutrients (TDN) $^{\mathrm{a}}$ & 70.92 & 83.67 & 86.29 \\
\hline
\end{tabular}

${ }^{a}$ Calculated with the formula proposed by Hartadi et al.(2005) 
might be caused by cellulose and hemicellulose bond that were terminated by cellulase enzyme and hemicellulase enzyme into simple bond.

The changing of nutrient composition was similar to the research done by Sutarjo et al. (2011), DM changed from $83.79 \%$ to $83.66 \%$, CP from $8.69 \%$ to $13.84 \%$, CF from $42.55 \%$ to $34.36 \%$, EE from $2.74 \%$ to $2.03 \%$ and TDN from $52.88 \%$ to 55.31 after one week fermentation.

\section{Consumption of Total Digestible Nutrients}

Statistical analysis showed that the TDN consumption was significantly $(\mathrm{P}<0.05)$ influenced by the difference of feed treatment, especially between the control feed with fermented complete feed. The fermented complete feed either one or two weeks were similar. Goats on treatment $\mathrm{R}_{0}$ (control feed) consumed TDN higher than goats fed with fermented complete feed. The mean consumption of TDN on $\mathrm{R}_{0}, \mathrm{R}_{1}$ and $\mathrm{R}_{2}$ were $57.57 \pm 15.81 \mathrm{~g} / \mathrm{kg} \mathrm{BW}^{0.75}, 36.22 \pm 5.23$ $\mathrm{g} / \mathrm{kg} \quad \mathrm{BW}^{0.75}$ and $42.67 \pm 5.09 \mathrm{~g} / \mathrm{kg} \quad \mathrm{BW}^{0.75}$, respectively.

The difference of TDN consumption in this research might be affected by the value of DM and CP of each diet. Siregar (1994) stated that TDN consumption can be affected by the nutrient content of the feed. TDN was digestible energy feed which come from nutrient content of feed such as crude protein, crude fiber, ether extract and extract materials without nitrogen.

Ngadiyono et al. (2009) stated that lamb with body weight of 10 to $20 \mathrm{~kg}$ requires TDN of 270 to $440 \mathrm{~g} / \mathrm{head} /$ day. The average of body weight of goat at the end of this research were 16 $\mathrm{kg}$ with TDN consumption were 506.58 $\mathrm{g} /$ head/day $\left(\mathrm{R}_{0}\right), 428.15 \mathrm{~g} /$ head/day $\left(\mathrm{R}_{1}\right)$ and $438.53 \mathrm{~g} /$ head/day $\left(\mathrm{R}_{2}\right)$. Consumption of TDN in this research was similar to the results research done by Kamalidin et al. (2012) being $351.08 \mathrm{~g} /$ head/day (fed with conventional feed) and 532.39 $\mathrm{g} /$ head/day (fed with complete feed fermentation). Kearl (1982) stated that the TDN requirement of goats to reach the body weight gain of 50 $\mathrm{g} / \mathrm{h}$ ead/day is $38.05 \mathrm{~g} / \mathrm{kg} \mathrm{BW}^{0.75}$. Thus, consumption of TDN in goat fed with fermented complete feed in this research had met the requirement.

\section{Fiber Digestibility}

Average of acid detergent fiber (ADF) and neutral detergent fiber (NDF) digestibility of Bligon goats is presented in Table 4.

\section{Acid Detergent Fiber (ADF) Digestibility}

There was no significant effect of treatment on ADF digestibility. Oluokun (2005) stated that the level of plant components that could not be digested (lignin and silica) is part of the ADF. It can cause low digestibility. In this research, the content of ADF was almost the same for all diet, so that the digestibility of ADF was also almost the same. Tillman et al. (1991) stated that percentage of crude fiber will increase in older plants. Thus, it usually characterized by the addition lignifications of cellulose and hemicellulose in the cell wall. Prawirokusumo (1994) stated that ADF is composed of lignin and cellulose that largely could not be digested.

\section{Neutral Detergent Fiber (NDF) Digestibility}

Statistical analysis showed that NDF digestibility was not significantly affected by feed treatment (fermentation). Crude fiber fraction influenced digestibility, because only a small fraction of fibers can be digested by microbes. Tillman et al. (1991) stated that crude fiber components that related to the digestibility of feed, were cellulose, hemicellulose and lignin. Lignin and silica could not be digested by digestive enzymes in ruminants. Therefore, cellulose and hemicellulose are substances that useful in the NDF. However, NDF content of the $R_{2}$ was lower than $R_{1}$. NDF is determiner major component of the cell wall such as cellulose, hemicellulose and lignin (Van Soest et al., 1994). Besides, it's probably because of the use of cells containing fat, sugars, organic acids, non-protein nitrogen, pectin, soluble proteins, and other water soluble materials (Suparjo, 2009). This condition

Table 4. Average ADF and NDF digestibility of Bligon goats with different feed treatments

\begin{tabular}{cccc}
\hline Parameters & $\mathrm{R}_{0}$ & $\mathrm{R}_{1}$ & $\mathrm{R}_{2}$ \\
\hline ADF & 51.20 & 48.45 & 49.19 \\
NDF & 78.56 & 71.06 & 75.15 \\
\hline
\end{tabular}


causes the fluctuations increase and decrease in NDF in fermented complete feed. After two weeks fermentation, NDF content decreased. This was consistent with the research done by Munier (2012) that seven and nine days fermentation using Aspergillus niger resulted NDF content of $89.44 \%$ and $92.84 \%$, respectively.

\section{Average Daily Gain (ADG)}

Results of research on the initial body weight, final body weight, and average daily gain between goats fed with fermented complete feed and fed with control feed is presented in Table 5. Statistical analysis showed that the treatment did not significantly affect the ADG of Bligon goat. Bligon goat fed with control feed tended to have higher of nutrient consumption than goats fed with fermented complete feed. However, the high consumption did not significantly affect to ADG. This was probably due to the feed digestibility did not differ.

However, there was a tendency that Bligon goat fed with control feed has higher ADG. This happens because goats fed with control feed consume more feed and nutrient (DM, CP, CF and TDN), finaly affected to higher body weight gain. Complete feed consisted of agricultural waste/ by product, so the consumption was not optimal when compared to controls. Parakkasi (1999) stated that the consumption of dry matter and organic matter can affect the ADG. Ration which has a high nutritional value and good digestibility levels can increase body weight during fattening period. Hamidah et al. (2011) stated that the main factor affect to ADG is total nutrients consumed and biological value of feed. Feed consumption was correlated with total energy and nutrient intake to promote growth and animal production, so that if feed consumption is high, the ADG will also high. Research done by Kleden (1996) using 8 to 12 months Bligon goats fed fresh forage and concentrates produced ADG ranged from 32.54 to

\section{$43.65 \mathrm{~g} / \mathrm{head} /$ day.}

\section{Farmer's income}

Feed costs typically represent $70 \%$ of the production cost in producing livestock. A necessary step, producers should make decisions based on profit income. Farmer's income was the income received from the results of animal body weight gain during the fattening period minus variable costs of feed. Farmer's income calculation is influenced by several factors, such as body weight gain, feed prices, and the amount of consumption during maintenance. Goats' price was used IDR 27,000 / kg live weight (fattening) and IDR 35,000/ $\mathrm{kg}$ body weight (fattened). The profit of goats during fattening periode is presented in Table 6 .

Statistical analysis showed that farmer's income was not significantly different among the three treatments, although there was a tendency that the Bligon goat fed with control feed $\left(\mathrm{R}_{0}\right)$ has higher farmer's income compared to $R_{1}$ and $R_{2}$ It might be caused by feed prices was quite expensive, while the average daily gain produced was low. $R_{1}$ and $R_{2}$ diet was consumed low than $\mathrm{R}_{0}$, resulting in a total feed costs were lower during maintenance. However, due to the resulting of average daily gain is low, this is an impact on the low value of the income. Based on Table 6, it can be explained that the lower feed costs did not always provide a better profit. Average farmer's income in this research was lower than research done by Kamalidin et al. (2012) goat fed with fermented complete feed (CBC) resulted income IDR. 139,203.15.

\section{CONCLUSION}

Based on research result, it can be concluded that fermented complete feed has a brownish yellow color, soft texture, not moldy, and the $\mathrm{pH}$ value ranged from 4.5 to 5 . Fermented complete

Table 5. Initial Body Weight, Final Body Weight and Average Daily Gain of Bligon Goat with Fifferent feed Treatments

\begin{tabular}{lccc}
\multicolumn{1}{c}{ Parameter } & $\mathrm{R}_{0}$ & $\mathrm{R}_{1}$ & $\mathrm{R}_{2}$ \\
\hline Initial body weight $(\mathrm{kg})$ & $13.04 \pm 0.32$ & $13.27 \pm 0.21$ & $14.28 \pm 0.38$ \\
Final body weights $(\mathrm{kg})$ & $16.93 \pm 1.10$ & $15.53 \pm 1.16$ & $16.71 \pm 0.44$ \\
Average daily gain $(\mathrm{g} /$ head/day) & $45.79 \pm 8.66$ & $34.66 \pm 10.91$ & $34.64 \pm 2.99$ \\
\hline
\end{tabular}


Table 6. Calculation of cost profit of Bligon goats

\begin{tabular}{lccc}
\hline \multicolumn{1}{c}{ Variables } & \multicolumn{1}{c}{$\mathrm{R}_{0}$} & $\mathrm{R}_{1}$ & $\mathrm{R}_{2}$ \\
\hline The purchase price (IDR/head) & 345,870 & 335,070 & 380,160 \\
The selling price (IDR/head) & 592,550 & 543,550 & 608,300 \\
Feed costs (IDR) & $120,964.31$ & $105,445.60$ & $106,833.70$ \\
Revenue (IDR): & & & \\
$\cdot$ per 3 months & 246,680 & 208,480 & 228,140 \\
$\cdot$ per 1 month & 82,226 & 69,493 & 76,046 \\
\hline
\end{tabular}

feed with two weeks fermentation has more pungent odor. Fermented complete feed for Bligon goats can affect consumption of total digestible nutrients, but does not affect the digestibility of NDF and ADF, average daily gain, and farmer's income. Fermented complete feed with local waste product can be used as an alternative feed mainly during the dry season when forage and legume are very limited.

\section{REFERENCES}

Djaafar, T.F., E. S. Rahayu, D. Wibowo and S. Sudarmadji. 1996. Substansi antimikrobia bakteri asam laktat dan diisolasi dari makanan hasil fermentasi tradisional Indonesia. Jurnal Ilmu Pertanian Indonesia 6:15-21

Crowder, L.V. and H.R. Chheda. 1982. Tropical Grassland Husbandry. Longman Group Ltd. London and New York.

Hamidah, A., C. I. Sutrisno, Sunarso, M. Christiyanto, L. K. Nuswantara and R. A. Muthalib. 2011. Performance of fat-tailed rams fed complete feed based oil palm fronds. J. Indonesian Trop. Anim. Agric. 36(3):185-189

Hartadi, H., S. Reksohadiprodjo and AD Tillman. 2005 Tabel Komposisi Pakan untuk Indonesia. Cetakan keempat. Gadjah Mada University Press, Yogyakarta.

Haryanto, B., I. Inounu and I.K.Sutama. 1997. Ketersediaan dan kebutuhan teknologi produksi kambing dan domba. Prosiding. Seminar Nasional Peternakan dan Veteriner. Bogor, 7-8 Januari 1997. Pusat Penelitian dan Pengembangan Pertanian. Departemen Pertanian. Bogor.

Kamalidin, A. Agus and I. G. S. Budisatria. 2012.
Performa Domba yang Diberi Complete Feed Kulit Buah Kakao Terfermentasi. Buletin Peternakan 36(3):162-168

Kearl, L.C. 1982. Nutrient Requirements of Ruminants In Developing Countries. Published by International Feedstuffs Institute, Utah State University, Logan, Utah.

Kleden, M.M. 1996 Kecernaan In vivo Hijauan Pakan Segar dan Konservasinya pada Kambing. Tesis. Fakultas Peternakan. Universitas Gadjah Mada. Yogyakarta.

Lendrawati., M., Ridla., and N. Ramli, 2008. Kualitas fermentasi dan nutrisi silase ransum komplit berbasis jagung, sawit dan ubi kayu in vitro. National Seminar on Animal Husbandry and Veterinary Technology. Post Graduate Faculty of Animal Science, Bogor Agricultural University, Bogor.

McDonald, I. 1981. A revised model for estimation of protein degradability in the rumen. J Agric. Sci.Camb. 96: 251-252.

Munier, F. F. 2012. Kajian fermentasi kulit buah kakao (Theobroma cacao L.) menggunakan Aspergillus spp. terhadap kecernaan dan konsumsi pada kambing Peranakan Etawah Jantan. Disertasi. Program Pascasarjana, Universitas Gadjah Mada, Yogyakarta.

Ngadiyono, N., Ismaya, H. Mulyadi, and S. Andarwati. 2009. Plasma Nutfah Ternak Domba di Indonesia. Fakultas Peternakan Universitas Gadjah Mada. Yogyakarta.

Nusi, M., R. Utomo and Soeparno. 2011. Pengaruh Penggunaan Tongkol Jagung dalam Complete Feed dan Suplementasi Undegraded Protein terhadap Pertambahan Bobot Badan dan Kualitas Daging pada Sapi Peranakan Ongole. Buletin Peternakan. 


\section{5(3):173-181}

Oluokun, J.A. 2005. Intake, digestion and nitrogen balance of diets blended with urea treated and untreated cowpea husk by growing rabbit. Afr. J. Biotechnol. 4(10):1203-1208

Parakkasi, A. 1999. Ilmu Nutrisi dan Makanan Ruminan. Universitas Indonesia Press. Jakarta.

Prawirokusumo, S. 1994. Ilmu Gizi Komparatif. First Edition. BPFE. Yogyakarta.

Purbowati, E., C. I. Sutrisno, E. Baliarti, S. P. S. Budhi and W. Lestriana. 2008. Energy utilization of complete feed with different protein-energy levels in male local lamb on feedlot system. J. Indon. Trop. Anim. Agric. 33(1):59-65

Siregar, S. B. 1994. Ransum Ternak Ruminansia. Penebar Swadaya. Jakarta.

Suparjo, K.G. Wiryawan, E.B. Laconi and D.
Mangunwidjaja.2009. Perubahan Komposisi Kimia Kulit Buah Kakao Akibat Penambahan Mangan dan Kalsium dalam Biokonversi dengan Kapang Phanaerochaete chrysosporium. Media Peternakan. 32:203-210

Sutarjo, K.G. Wiryawan, E.B. Laconi and D. Mangunwidjaja, 2011. Performa Kambing yang Diberi Kulit Buah Kakao Terfermentasi. Media Peternakan 29:35-41

Tillman, A.D., S. Reksohadiprojo, S. Prawirokusumo, S. Lebdosoekojo and $\mathrm{H}$. Hartadi, 1991. Ilmu Makanan Ternak Dasar. Gadjah Mada University Press. Yogyakarta.

Van Soest, P. J. 1994. Nutritional Ecology of The Ruminant. $2^{\text {nd }}$ edition. Cornell University Press. Ithaca, USA.

Wallace, R.J. and C. Chesson. 1995. Biotechnology in Animal Feeds and Animal Feeding. Winheim. Ithaca and London. 